\title{
PENERAPAN SISTEM MANAJEMEN INFORMASI OBYEK PAJAK (SISMIOP) SEBAGAI SARANA PENINGKATAN PELAYANAN DAN PENERIMAAN PAJAK BUMI DAN BANGUNAN DI KABUPATEN BUOL
}

\author{
Ardiansyah M. Kadadia ${ }^{1}$ \\ Jullie J. Sondakh ${ }^{2}$ \\ Treesje Runtu ${ }^{3}$ \\ ${ }^{1,2}$ Fakultas Ekonomi dan Bisnis, Jurusan Akuntansi \\ Universitas Sam Ratulangi \\ Email : ${ }^{1}$ ardiankadadia@yahoo.co.id
}

\begin{abstract}
Tax property, urban and rural is a local tax was previously managed by the central government. In the year 2011 has been transferred to the regional governments together with SISMIOP. This is due lack of optimization $P B B-P 2$ and SISMIOP as well as the central government gives full authority to local goverments so as to maximize the revenues from the tax. The purpose of this research is how the comparison application SISMIOP, is SISMIOP can improve service and reception as well as obstacless ancountered in the implementation of SISMIOP in Buol district. The method used for this research is the qualitative method that use observation, interviews with tax officials and documents processing. The results showed that application of SISMIOP in Buol district accordance with applicable rules and implementation SISMIOP can be more simple, fast and efficient. This is evidenced by the increasing aaceptance of the PBB-P2 once transferred to local government. Increased acceptance PBB-P2 can not be separated from continue doing the billing to the taxpayeer.
\end{abstract}

Keyword: SISMIOP, Services, Income 


\section{PENDAHULUAN}

\section{Latar belakang}

Sebagai salah satu negara berkembang di dunia, Indonesia terus melakukan pembangunan di berbagai sektor di seluruh wilayah di Indonesia. Pembangunan ini membutuhkan anggaran yang tidak sedikit. Maka dari itu Pemerintah terus melakukan pengoptimalisasian terhadap penerimaan-penerimaan negara. Salah satu pengoptimalisasian penerimaan yang terus dilakukan adalah pajak.

Pajak merupakan salah satu sumber penerimaan ataupendapatan terbesar negara. Salah satu pajak yang memberikan kontribusi terhadap negara adalah pajak bumi dan bangunan (PBB). Pajak Bumi dan Bangunan (PBB) adalah pajak yang bersifat kebendaan dalam arti besarnya pajak terutang ditentukan oleh keadaan objek yaitu bumi/tanah atau bangunan. Ada beberapa klasifikasi untuk objek pajak bumi dan bangunan, salah satunya sektor perkotaan dan perdesaan atau disebut PBB-P2.Sebelum tahun 2011 pajak bumi dan bangunan perkotaan perdesaan ini dikelola oleh pemerintah pusatdan telah diserahkan atau dialihkan kepada pemerintah daerah sebagaimana tindak lanjut dari kebijakan otonomi daerah dan desentralisasi fiskal.

Dengan pengalihan ini maka kegiatan proses pendataan, penilaian, penetapan, pengadministrasian, pemungutan/penagihan dan pelayan PBB-PP akan diselenggarakan oleh pemerintah daerah (kabupaten/kota). Pemerintah daerah harus sepenuhnya menyadari bahwa agenda pengalihan PBB-PP ini merupakan pekerjaan besar, selain dihadapkan pada beberapa kendala, rencana ini juga membutuhkan waktu dan perencanaan yang matang agar prosesnya berjalan dengan baik dan memberikan hasil yang optimal. Kendala tersebut antara lain kesiapan sumber daya manusia, proses pemungutan PBB perdesaan dan perkotaan memerlukan kesiapan sumber daya manusia (SDM) pada pemda yang nantinya akan melaksanakan pengadministrasian PBB secara otonom.

Berdarsarkan hal tersebut pemerintah dalam hal ini Dirjen Pajak dan Kementrian Keuangan menciptakan sistem administrasi perpajakan modern untuk memberikan pelayanan yang baik dan meningkatkan penerimaan yang disebut SISMIOP (Sistem Manajemen Informasi Objek Pajak). SISMIOP menurut Dirjen Pajak merupakan sistem yang terintegrasi untuk mengolah informasi/data objek dan subjek pajak bumi dan bangunan dengan bantuan komputer sejak dari pengumpulan data (melalui pendaftaran, pendataan dan penilaian) pemberian identitas objek pajak (nomor objek pajak), perekaman data, pemeliharaan basis data, pencetakan hasil keluaran (berupa SPPT, STTS, DHKP, dan sebagainya), pemantauan penerimaan dan pelaksanaan penagihan pajak, sampai dengan pelayanan kepada wajib pajak melalui pelayanan satu tempat.

SISMIOP sendiri telah dilaksanakan oleh pemerintah pusat untuk membantu pengelolaan objek dan subjek PBB-P2. Namun pengelolaan yang dilakukan pemerintah pusat kurang optimal dalam memaksimalkan penerimaan dari sektor PBB-P2.Misalnya dalam hal pembaharuan data objek dan subjek PBB-P2 yang kurang jelas. Selain itu pengalihan PBB-P2 dan SISMIOP kepada pemerintah daerah untuk memberikan wewenang penuh kepada pemda agar dapat dikelola dengan maksimal.

\section{Tujuan Penelitian}

1. Untuk mengetahui perbandingan penerapan SISMIOP di Pemerintah Pusat dan Pemerintah Daerah.

2. Untuk mengetahui apakah ada peningkatan pelayanan dan penerimaan PBB-P2.

3. Untuk mengetahui masalah atau kendala dalam penerapan SISMIOP di Kabupaten Buol.

\section{TINJAUAN PUSTAKA}

\section{Pajak Bumi dan Bangunan (PBB)}

Pajak bumi dan bangunan (PBB) adalah pajak negara yang dikenakan terhadap bumi dan atau bangunan berdasarkan undang-undang nomor 12. Tahun 1985 tentang pajak bumi dan bangunan sebagaimana telah diubah dengan undang-undang nomor 12. Tahun 1994. Menurut Dirjen Pajak, PBB adalah pajak yang bersifat 
kebendaan dalam arti besarnya pajak terutang ditentukan oleh keadaan objek yaitu bumi/tanah dan atau bangunan. Keadaan subjek (siapa yang membayar) tidak ikut menentukan besarnya pajak (Nadhia, et al : 2014). Selain itu, Pajak Bumi dan Bangunan (PBB) biasanya didefinisakan sebagai pajak yang dikenakan pada orang pribadi atau badan yang nilainya bergantung pada tanah dan bangunan itu sendiri (L. Cameron, 1999).

\section{Pajak Bumi dan Bangunan Perkotaan Perdesaan (PBB-P2) Sebagai Pajak Daerah}

Menurut Undang-Undang Nomor 28 Tahun 2009, Pajak Bumi dan Bangunan adalah pajak atas bumi dan/atau bangunan yang dimiliki, dikuasai, dan/atau dimanfaatkan oleh orang pribadi atau badan, kecuali kawasan yang digunakan untuk kegiatan usaha perkuburan, perhutanan, dan pertambangan. Tarif Pajak Bumi dan Bangunan Perkotaan dan Perdesaan ditetapkan adalah paling tinggi sebesar 3\%. PBB-P2 wewenang pemungutannya diserahkan kepada pemerintah daerah dan hasilnya masuk ke kas daerah sebagai pajak daerah (Jacob Ratuela, et al : 2015).

\section{SISMIOP}

Menurut Keputusan Direktorat Jendral Pajak Nomor kep-533/Pj/2000 Tentang Petunjuk Pelaksanaan Pendaftaran, Pendataan dan Penilaian Objek dan Subjek Pajak Bumi dan Bangunan Dalam Rangka Pembentukan dan atau Pemeliharaan Basis Data Sistem Manajemen Informasi Objek Pajak (SISMIOP), SISMIOP adalah sistem yang terintegrasi untuk mengolah pengumpulan data (melalui pendaftaran, pendataan dan penilaian) pemberian identitas objek pajak (nomor objek pajak), perekam data, pemeliharaan basis data, pencetakan hasil keluaran, pemantauan penerimaan dan pelaksanaan penagihan pajak.

\section{Tahapan SISMIOP}

SISMIOP merupakan sebuah sistem manajemen PBB-PP yang terintegrasi. Untuk membentuknya memerlukan beberapa tahapan yang sesuai dengan pengertian Keputusan Direktorat Jenderal Pajak Nomor KEP-05/PJ.6/1994 Tentang Pelaksanaan SISMIOP Pajak Bumi dan Bangunan (PBB) Tahun Anggaran 1994/1995. Tahapan tersebut sebagai berikut (Wahyudi, 2013) :

1. Pendaftaran Objek dan Subjek Pajak.

2. Pendataan Objek dan Subjek Pajak.

3. Penilaian
a. Penilaian Massal

b. Penilaian Individu

4. Pemberian Identitas Objek Pajak (NOP).

5. Perekaman Data.

a. Perekaman ZNT dan DBKB

b. Perekaman SPOP

6. Pemeliharaan Basis Data

7. Pencetakan Hasil Keluaran.
a. Surat Pemberitahuan Pajak Terutang (SPPT).
b. Surat Tanda Terima Setoran (STTS).
c. Daftar Himpunan Ketetapan Pajak (DHKP).
8. Pemantauan Penerimaan/Pembayaran.
9. Pelayanan Satu Tempat.

\section{Jenis Penelitian}

\section{MOTEDE PENELITIAN}

Jenis penelitian yang digunakan dalam penulisan skripsi ini adalah penelitian kualitatif, yaitu data yang mencakup hampir semua data non-numerik. Data ini dapat menggunakan kata-kata untuk menggambarkan fakta dan fenomena yang diamati.

\section{Tempat dan Waktu Penelitian}


Adapun tempat penelitian ini dilakukan di Dinas Pendapatan Daerah (DPPKAD) Kabupaten Buol. Proses pengumpulan dan pengolahan data untuk penelitian ini memakan waktu 3 (tiga) bulan yaitu dimulai dari bulan Desember 2015 s/d Februari 2016.

\section{Metode Analisis}

Metode analisis data adalah suatu metode yang digunakan untukmengelolah hasil penelitian guna memperoleh suatu kesimpulan. Dengan melihat kerangka pemikiran teoritis, maka teknik analisis data yang digunakan dalam penelitian ini analisis komparatif, yaitu suatu penelitian yang sifatnya membandingkan. Disini variabelnya masih sama dengan variabel mandiri tetapi untuk sampel yang lebih dari satu atau dalam waktu yang berbeda. Penggambaran kondisi bisa individual atau menggunakan angka-angka. Dan mendeskripsikan, gambaran atau lukisan secara sistematis serta menghubungkan antar fenomena yang diteliti.

Untuk mengetahui efektivitas penerapan SISMIOP di Kabupaten Buol maka digunakan rumus rasio efektivitas yang dapat dilihat dari rencana penerimaan dan realisasi PBB-P2. Rumus rasio efektivitas (Ayu, et al : 2015) :

Efektivitas $=\frac{\text { Realisasi Penerimaan } P B B-P 2}{\text { Rencana Penerimaan } P B B-P 2} \times 100 \%$

Untuk mengetahui suatu efektivitas, maka digunakan kriteria yang dijelaskan Tabel 1 sebagai berikut :

Tabel 1 Kriteria Efektivitas dalam penerapan SISMIOP

\begin{tabular}{ll}
\hline Kemampuan Efektivitas & Rasio \\
\hline Sangat Efektif & $>100$ \\
\hline Efektif & $90-100$ \\
\hline Cukup Efektif & $80-90$ \\
\hline Kurang Efektif & $60-80$ \\
\hline Tidak Efektif & $<60$
\end{tabular}

Sumber : KEP. MENDAGRI NO. 690.900-327, 1967 (Sharon Sumenge, 2013)

\section{HASIL PENELTIAN DAN PEMBAHASAN}

\section{Gambaran Umum DPPKAD Kabupaten Buol}

VISI

“Optimalisasi Pengelolaan Keuangan Daerah menuju Pemerintahan yang Bersih dan Baik"

Visi ini merupakan cara pandang jauh kedepan tentang pengelolaan keuangan daerah Kabupaten Buol yang harus diwujudkan, dengan pengertian sebagai berikut :

\section{Optimalisasi.}

Sikap, kebijakan dan tindakan yang profesional, cakap dan kreatif dalam pelaksanaan kegiatan berdasarkan peraturan perundang-undangan dengan didukung sarana dan prasarana sehingga memperoleh hasil yang maksimal.

\section{Pengelolaan Keuangan Daerah.}

Penyelenggaraan penatausahaan keuangan daerah yang meliputi penyusunan anggaran, pengelolaan pendapatan, pelaksanaan anggaran, pengelolaan asset daerah beserta laporan atas pertanggungjawaban dimana Dinas Pendapatan Pengelolaan Keuangan dan Aset Daerah sebagai Entitas Akuntansi dan Entitas Pelaporan yang transparan dan akuntable serta meningkatkan pelayanan yang maksimal.

\section{Pemerintahan yang Bersih dan Baik.}

Pemerintahan yang bebas dari korupsi, kolusi dan nepotisme dengan berpedoman pada peraturan perundangan yang berlaku sehingga dapat terwujud penatausahaan keuangan dan aset daerah yang transparan, efektif, efisien dan akuntabel. 


\section{MISI}

Oleh karena itu Dinas Pendapatan Pengelolaan Keuangan dan Aset Daerah Kabupaten Buol menetapkan Misi guna menjabarkan rumusan dan makna yang terkandung dalam Visi di atas, adalah sebagai berikut :

1) Meningkatkan Kapasitas Kelembagaan dan Kompetensi sumber daya manusia dibidang pengelolaan keuangan daerah.

2) Meningkatkan pendapatan daerah melalui intensifikasi dan ekstensifikasi.

3) Penatausahaan pengelolaan keuangan dan aset daerah yang transparan dan akuntabel.

\section{Hasil Penelitian}

\section{Penerapan SISMIOP di Kabupaten Buol}

Penerapan SISMIOP dilaksanakan pada tahun 2014 bersamaan dengan dialihkannya PBB-P2 kepada pemerintah daerah. Sistem Manajemen Informasi Objek Pajak (SISMIOP) merupakan aplikasi yang membantu aparat pajak dalam melakukan pendataan hingga pelayanan satu tempat. Dinas Pendapatan Pengelolaan Keuangan Aset Daerah (DPPKAD) Kabupaten Buol memiliki seksi-seksi atau bagian-bagian yang memiliki tugas masing-masing dalam pelayanan PBB-P2, yaitu :

1) Bagian Pelayanan, bertugas melayani wajib pajak misalnya pembayaran PBB-P2, penyerahan berkas pengajuan keberatan, pengurangan dan balik nama, dan lain-lain.

2) Bagian Verifikasi, bertugas menyortir data-data yang dibutuhkan atau digunakan dalam pendataan/penetapan.

3) Bagian Pendataan/Penilaian, bertugas untuk melakukan pendataan dan penilaian objek pajak PBB-P2.

4) Bagian Data dan Informasi, bagian ini bertugas melakukan perubahan data komputer, pencetakan SPPT.

Gambar 1 merupakan alur atau flowchart mengenai pelayanan PBB-P2 yang dilaksanakanoleh Dinas Pendapatan Pengelolaan Keuangan Aset Daerah(DPPKAD) Kabupaten Buol terhadap wajib pajak :

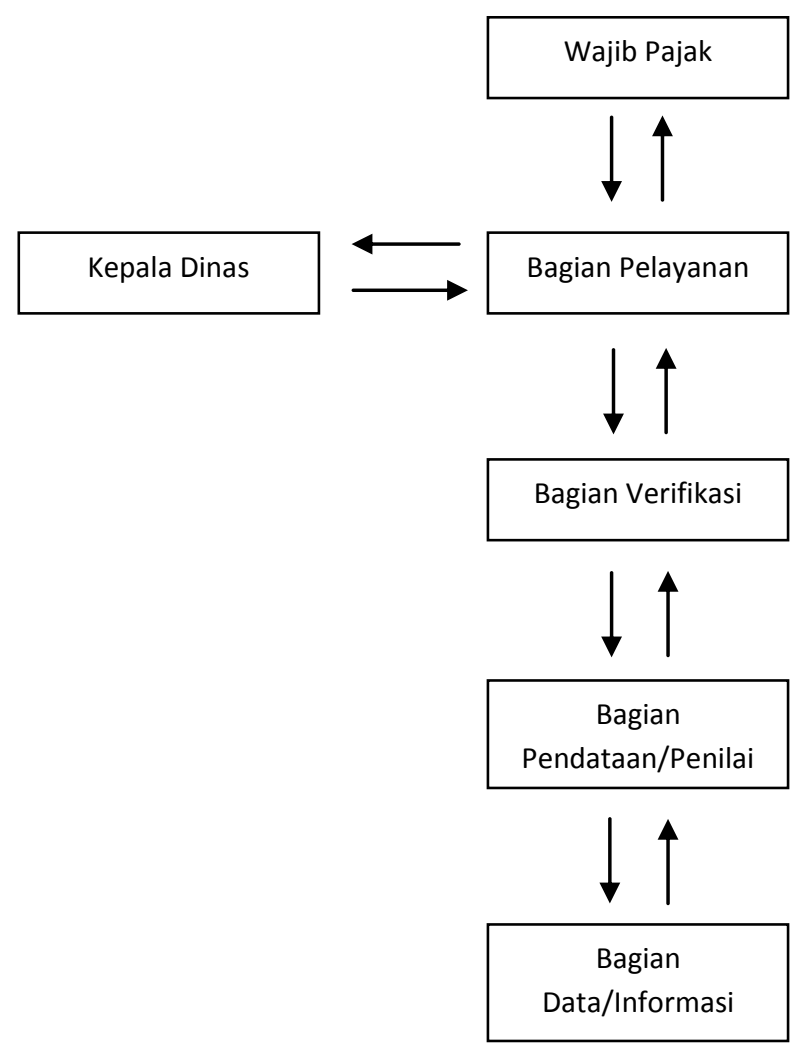

Gambar 1 Sumber Data : DPPKAD Kabupaten Buol "Alur Pelayanan PBB-P2" 
Berdasarkan Keputusan Dirjen Pajak nomor Keputusan Direktorat Jenderal Pajak Nomor KEP05/PJ.6/1994 Tentang Pelaksanaan SISMIOP Pajak Bumi dan Bangunan (PBB) Tahun Anggaran 1994/1995 bahwa tahapan SISMIOP yang telah disebutkan telah sesuai dan dilaksanakan oleh DPPKAD Kabupaten Buol. Berikut merupakan tahapan SISMIOP yang ada di Kabupaten Buol :

\section{Pendaftaran Objek dan Subjek Pajak}

Wajib pajak dapat melakukan pendaftaran objek pajak dan subjek pajak baru di Dinas Pendapatan Pengelolaan Keuangan Aset Daerah (DPPKAD) tepatnya di bidang pelayanan. Di bidang ini WP akan diberikan Surat Pemberitahuan Objek Pajak (SPOP) untuk diisi oleh wajib pajak dengan benar, jelas dan lengkap kemudian dikembalikan lagi kepada aparat pajak untuk dilakukan pendataan. Pengembalian SPOP ke tempat pengambilan atau kantor pelayanan paling lambat 30 hari sejak SPOP diterima oleh wajib pajak. Terlambat mengembalikan SPOP akan dikenakan denda administrasi $25 \%$ dari pajak terutang. SPOP sendiri tidak hanya didapatkan di DPPKAD saja, tetapi kantor lurah/camat menyediakan lembar SPOP tersebut.

\section{Pendataan dan Penilaian}

Setelah SPOP telah diterima oleh aparat pajak maka akan dilakukan pendataan mengenai hal-hal yang berkaitan dengan objek pajak yang telah diisi oleh wajib pajak kedalam SPOP. Misalnya luas tanah, bangunan, letak objek pajak tersebut, dan lain sebagainya.

Setelah dilakukan pendataan maka akan dilakukan penilaian. DPPKAD Kabupaten Buol telah memiliki bagian yang bertugas untuk melakukan pendataan dan penilaian yakni bagian pendataan/penilaian yang ada di Bidang Pendapatan.

\section{Pemberian Identitas Objek Pajak (NOP) dan Perekaman Data}

Bidang pendataan/penilaian di DPPKAD Kabupaten Buol salah satunya melakukan tugas pemberian nomor objek pajak dan perekaman data setelah dilakukannya pendataan dan penilaian. Nomor Objek Pajak (NOP) merupakan nomor unik yang menunjukan identitas tiap-tiap objek pajak. Ciri-ciri yang melekat pada NOP adalah unik, permanen dan standar.

Sedangkan untuk perekaman data yaitu perekaman Zona Nilai Tanah (ZNT), Daftar Biaya Komponen Bangunan (DBKB) serta SPOP. Perekaman dimaksudkan untuk memasukan kode ZNT berdasarkan NIR kedalam aplikasi SISMIOP. DBKB dilakukan dengan cara memasukan harga bahan bangunan dan upah pekerja dari setiap wilayah kabupaten/kota. Sedangkan SPOP akan dimasukkan ke dalam aplikasi setelah ZNT dan DBKB terlebih dahulu dimasukan. Akan dilakukan penilaian massal dan akan menghasilkan NJOP Bumi dan NJOP Bangunan.

\section{Pemeliharaan Basis Data}

Pemeliharaan data dapat dilakukan langsung oleh DPPKAD Kabupaten Buol setelah PBB-P2 diserahkan kepada Pemerintah Daerah. DPPKAD secara aktif memperbaharui data mengenai daerah-daerah yang banyak melakukan perubahan-perubahan, misalnya tanah kosong yang kemudian diatasnya sudah dibuat bangunan, bangunan yang melakukan renovasi sehingga perlu didata ulang.

Pemuktahiran data juga dapat dilakukan atas permintaan atau permohonan wajib pajak mengenai keberatan, balik nama, pemecahan objek pajak, dan pembatalan SPPT. Pemuktahiran data dalam hal ini melakukan pendataan kembali objek pajak wajib pajak yang bersangkutan. Dalam pemuktahiran basis data Pemerintah Kabupaten Buol telah mengatur proses tersebut. Setiap tahun DPPKAD telah mencanangkan memperbaharui data sebab data yang terdapat pada DPPKAD Kab. Buol adalah data sebelum SISMIOP diterapkan. Hal ini banyak terdapat perubahan dalam hal kepemilikan objek pajak tersebut.

\section{Pencetakan Massal}

Pencetakan massal dilakukan setelah diadakannya pemuktahiran basis data agar SPPT yang akan dicetak sudah sesuai dengan data yang terakhir. Selain itu ditetapkan juga jatuh tempo pembayaran SPPT dalam pencetakkan massal. 


\section{Penyerahan SPPT}

Penyampain SPPT ke wajib pajak sangat menentukan keberhasilan penerimaan PBB-P2. Wajib pajak yang terlambat menerima SPPT dapat mengajukan keberatan atas jatuh tempo dalam SPPT tersebut. Karena sesuai ketentuan jatu tempo adalah enam bulan setelah diterimanya SPPT.

\section{Tata Cara Pembayaran}

Dalam perda nomor 12 tahun 2013 pasal 22 dijelaskan apabila pajak terutang pada saat jatuh tempo pembayaran tidak dibayarkan atau kurang bayar maka dikenakan denda sebesar $2 \%$ (dua persen) sebulan yang terhitung dari saat jatuh tempo sampai pembayaran untuk jangka waktu paling lama 24 (dua puluh empat) bulan.

Pembayaran pajak terutang dapat dilakukan ditempat yang telah ditunjuk oleh pemda setempat. Wajib pajak dapat membayar pajak terutang di bank yang telah bekerja sama dengan pemeritah daerah atau melakukan pembayaran pada petugas pemungut pajak.

\section{Pelayanan Ke Wajib Pajak}

Jangka waktu penyelesaian permohonan pelayanan PBB-P2 oleh DPPKAD Kabupaten buol paling cepat adalah 5 hari. Tabel 2 merupakan jumlah wajib pajak yang melakukan keberatan, objek pajak baru, mutasi, pembetulan/penghapusan, penerbitan salinan SPPT pada tahun 2015 :

Tabel 2 Penyelesaian Permohonan Pelayanan PBB-P2 di Kab. Buol Tahun 2015

\begin{tabular}{llll}
\hline No. & Jenis Pelayanan & Jumlah Masuk & Jumlah Selesai \\
\hline 1. & Keberatan & 15 & 15 \\
\hline 2. & Mutasi & 34 & 34 \\
\hline 3. & Penghapusan/Pembetulan & 50 & 50 \\
\hline 4. & Salinan SPPT & - & - \\
\hline 5. & OP Baru & 164 & 164 \\
\hline
\end{tabular}

Sumber : DPPKAD Kabupaten Buol

\section{Pembahasan}

\section{Perbandingan Tahapan SISMIOP}

Perbandingan tahapan SISMIOP yang dilaksanakan oleh DPPKAD Kabupaten Buol dengan tahapan SISMIOP sesuai pengertian Dirjen Pajak dalam Keputusan Dirjen Pajak Nomor Kep-05/PJ.6/1994 Tentang Pelaksanaan Sistem Manajemen Informasi Objek Pajak (SISMIOP) PBB Tahun Anggaran 1994/1995 dengan penjelasan lebih lanjut oleh Wahyudi :

Tabel 3 Perbandingan Tahapan SISMIOP oleh Waluyo dan DPPKAD Kabupaten Buol

\begin{tabular}{|c|c|c|c|c|}
\hline No. & $\begin{array}{l}\text { Tahapan } \\
\text { SISMIOP }\end{array}$ & $\begin{array}{c}\text { Tahapan SISMIOP Keputusan } \\
\text { Dirjen Pajak Nomor Kep- } \\
\text { 05/PJ.6/1994 }\end{array}$ & $\begin{array}{c}\text { Tahapan SISMIOP DPPKAD Kab. } \\
\text { Buol }\end{array}$ & Ket. \\
\hline 1. & Pendaftaran & $\begin{array}{l}\text { Pendaftaran objek pajak } \\
\text { dilakukan dengan mengisi } \\
\text { ditempat yang telah ditunjuk } \\
\text { Dirjen Pajak }\end{array}$ & $\begin{array}{l}\text { Wajib pajak dapat melakukan } \\
\text { pendaftaran Objek pajak di Bidang } \\
\text { Pelayanan di DPPKAD dengan } \\
\text { mengisi SPOP dengan benar, jelas } \\
\text { dan lengkap }\end{array}$ & Sesuai \\
\hline 2. & $\begin{array}{l}\text { Pendataan } \\
\text { Objek dan } \\
\text { Subjek Pajak }\end{array}$ & $\begin{array}{l}\text { Setelah mengisi SPOP maka akan } \\
\text { dilakukan } \\
\text { pendataan mengenai obejk pajak baru } \\
\text { tersebut }\end{array}$ & $\begin{array}{l}\text { Pendataan akan dilakukan oleh Seksi } \\
\text { Pendataan/Penilaian setelah data-data } \\
\text { yang dibutuhkan telah diverifikasi } \\
\text { dulu oleh Seksi Verifikasi }\end{array}$ & Sesuai \\
\hline 3. & Penilaian & $\begin{array}{l}\text { Setelah dilakukannya Pendataan maka } \\
\text { akan dilakukan Penilaian untuk NJOP } \\
\text { dari objek pajak tersebutdengan }\end{array}$ & $\begin{array}{l}\text { Seksi Pendataan/Penilaian melakukan } \\
\text { penilaian dengan pendekatan } \\
\text { penilaian massal atau individu, }\end{array}$ & Sesuai \\
\hline
\end{tabular}


pendekatan penilaian massal atau penilaian ini sebagai dasar NJOP dari individu objek pajak tersebut

\begin{tabular}{|c|c|c|c|c|}
\hline 4. & $\begin{array}{l}\text { Pemberian } \\
\text { Identitas Objek } \\
(\mathrm{NOP})\end{array}$ & $\begin{array}{l}\text { Nomor Objek Pajak (NOP) diberikan } \\
\text { pada saat dilakukannya pendaftaran } \\
\text { atau pendataan }\end{array}$ & $\begin{array}{l}\text { Seksi Pelayanan yang bertugas } \\
\text { memberi NOP pada saat objek pajak } \\
\text { baru didaftarkan }\end{array}$ & Sesuai \\
\hline 5. & Perekaman Data & $\begin{array}{l}\text { Proses memasukan data-data kedalam } \\
\text { aplikasi SISMIOP untuk dilakukan } \\
\text { penilaian massal sehingga } \\
\text { menghasilkan NJOP Bumi dan NJOP } \\
\text { Bangunan }\end{array}$ & $\begin{array}{l}\text { Data OP Bumi, ZNT-NIR, OP } \\
\text { Bangunan, DBKB merupakan data } \\
\text { yang akan dimasukkan kedalam } \\
\text { aplikasi SISMIOP untuk dilakukan } \\
\text { penilaian massal dan menghasilkan } \\
\text { NJOP Bumi dan NJOP Bangunan }\end{array}$ & Sesuai \\
\hline 6. & $\begin{array}{l}\text { Pemeliharaaan } \\
\text { Basis Data }\end{array}$ & $\begin{array}{l}\text { Pemeliharaan basis data merupakan } \\
\text { tahapan sismiop yang apabila data- } \\
\text { data objek pajak mengalami } \\
\text { perubahan sehingga data harus } \\
\text { diperbaharui }\end{array}$ & $\begin{array}{l}\text { Pembaharuan basis data dilakukan } \\
\text { oleh Seksi Data/Informasi di } \\
\text { DPPKAD ini dimaksudkan agar data } \\
\text { menjadi akurat }\end{array}$ & Sesuai \\
\hline 7. & $\begin{array}{l}\text { Pencetakan } \\
\text { Hasil Keluaran }\end{array}$ & Mencetak SPPT, STTS, DHKP & $\begin{array}{l}\text { Setelah dilakukan pembaharuan basis } \\
\text { data maka akan dilakukan Pencetakan } \\
\text { Massal berupa SPPT, STTS dan } \\
\text { DHKP serta daftar tuggakan }\end{array}$ & Sesuai \\
\hline 8. & $\begin{array}{l}\text { Pemantauan } \\
\text { Penerimaan } \\
\text { atau } \\
\text { Pembayaran }\end{array}$ & $\begin{array}{l}\text { Pembayaran dapat dilakukan ditempat } \\
\text { yang ditunjuk oleh Pemerintah } \\
\text { Daerah }\end{array}$ & $\begin{array}{l}\text { Pembayaran dapat dilakukan di Bank } \\
\text { yang terlah bekerja sama dengan } \\
\text { pemda setempat atau kepada aparat } \\
\text { pajak yang terlah ditunjuk oleh } \\
\text { Pemerintah Daerah }\end{array}$ & Sesuai \\
\hline 9. & $\begin{array}{l}\text { Pelayanan Satu } \\
\text { Tempat }\end{array}$ & $\begin{array}{l}\text { Permohonan yang diajukan oleh wajib } \\
\text { pajak dapat diselesaikan disatu tempat } \\
\text { tanpa harus ketempat yang lainya }\end{array}$ & $\begin{array}{l}\text { Penyelesaian permohonan wajib } \\
\text { pajak berupa pembetulan SPPT, dll } \\
\text { dapat dilakukan di satu tempat yakni } \\
\text { DPPKAD, sehingga lebih efisien }\end{array}$ & Sesuai \\
\hline
\end{tabular}

\section{Sumber : Data olahan, 2016}

Berdasarkan Tabel 3 Tahapan SISMIOP menurut Keputusan Dirjen Pajak Nomor Kep-05/PJ.6/1994 yang telah sesuai dengan yang ada di Dinas Pendapatan Pengelolaan Keuangan Aset Daerah Kabupaten Buol. Namun demikian, tahapan tersebut sudah terdapat pada tugas yang dilakukan oleh seksi-seksi yang ada di bagian pendapatan DPPKAD. Sehingga hal ini lebih memudahkan dalam pelaksanaan SISMIOP di Kabupaten Buol.

\section{Pelayanan Kepada Wajib Pajak dan Realisasi Penerimaan}

Bagian pelayanan di DPPKAD kabupaten buol menangani berbagai macam permohonan wajib pajak yang mengalami permasalahan dalam utang pajak yang WP ajukan. Kemudian setelah dilayani dilakukan verifikasi untuk menilai kelengkapan berkas yang diperlukan dan diberi perkiraan waktu penyelesaian permohonan tersebut. Dari data yang diperoleh bahwa semua pelayanan dapat diselesaikan dengan tepat waktu atau lebih cepat. Tahun 2015 semua permohonan yang diajukan oleh wajib pajak telah selesai dilaksanakan. Waktu paling cepat untuk menyelesaikan permohonan wajib pajak adalah 5(lima) hari tergantung dari permohonan yang diajukan oleh wajib pajak. Berdasarkan hal tersebut peneliti berpendapat bahwa penerapan SISMIOP di DPPKAD Kabupaten Buol merupakan sarana untuk meningkatkan pelayanan ke wajib pajak. SISMIOP yang didukung dengan sistem komputerisasi sehingga pekerjaan dapat diselesaikan dengan cepat dan juga wajib pajak dapat menyelesaikan permohonannya disatu tempat serta waktu yang dibutuhkan lebih efisien. 
Setelah PBB-P2 telah diserahkan atau dikelola oleh pemerintah daerah dan telah diterapkan pula SISMIOP di DPPKAD. Maka pemerintah daerah sendiri menargetkan jumlah penerimaan untuk sektor PBB-P2 senilai Rp 1.000.000.000 (satu milyar rupiah). Tabel 3 merupakan target dan realisasi setelah PBB-P2 dikelola oleh pemerintah dan diterapkannya SISMIOP serta tingkat efektivitas PBB-P2 tahun 2014-2015:

Tabel 4 Target dan Realisasi PBB-P2 2014-2015

\begin{tabular}{ccccc}
\hline Tahun & $\begin{array}{c}\text { Rencana } \\
(\mathbf{R p})\end{array}$ & $\begin{array}{c}\text { Realisasi } \\
(\mathbf{R} \mathbf{)})\end{array}$ & $\begin{array}{c}\text { Persentase } \\
(\mathbf{\%})\end{array}$ & Tingkat Efektivitas \\
\hline 2014 & 1.000 .000 .000 & 985.982 .334 & 98,59 & Efektif \\
\hline 2015 & 1.000 .000 .000 & 878.527 .365 & 87,85 & Cukup Efektif \\
\hline
\end{tabular}

Sumber : DPPKAD Kabupaten Buol

Dari Tabel 4 dapat diperoleh bahwa dengan dialihkannya PBB-P2 kepada pemerintah daerah dan didukung penggunaan SISMIOP dapat meningkatkan pendapatan daerah. Peningkatan ini dapat dilihat dari pokok PBB-P2 sebelum dikelola oleh DPPKAD Kabupaten Buol yang rata-rata berkisar Rp 800.000.000 (delapan ratus juta rupiah), namun setelah tahun 2014 PBB-P2 yang dikelola oleh DPPKADdan diterapkannya SISMIOP, pokok PBB-P2 mengalami peningkatan yakni sebesar lebih dari Rp 1.000.000.000 (satu milyar rupiah) dengan realisasi tahun $2014 \mathrm{Rp}$ 985.982.334 dan $2015 \mathrm{Rp}$ 878.527.365.

Penerapan SISMIOP di Kabupaten Buol didukung dengan adanya Peraturan Daerah nomor 12 tahun 2013 tentang Pajak Bumi dan Bangunan Perdesaan Perkotaan (PBB-P2), sangat mempengaruhi peningkatan realisasi penerimaan di Kabupaten Buol.

\section{Kendala Yang Dihadapi}

Namun demikian masih ada kekurangan dalam penerapan SISMIOP di Kabupaten Buol, yaitu belum adanya penerapan denda yang diberikan kepada wajib pajak apabila tidak membayar pajak atau telat membayar utang pajak. Hal ini juga dapat mengurangi penerimaan PBB-P2. Selain itu wajib pajak juga masih banyak yang belum sadar akan kewajibannya untuk membayar utang pajaknya. Hal ini dapat dilihat dari pokok pajak yang seharusnya diterima lebih dari Rp 1.000.000.000 akan tetapi realisasinya hanya berjumlah $\mathrm{Rp} 985.982 .334$ untuk tahun 2014 dan 2015 sebesar Rp 878.527.365.

Hal ini menjadi perhatian pemerintah setempat untuk terus menerus melakukan penagihan utang pajak kepada WP, agar penerimaan pajak untuk sektor PBB-P2 dapat tercapai secara maksimal.

\section{PENUTUP}

\section{Kesimpulan}

a. Penerapan SISMIOP PBB-P2 di Kabupaten Buol telah sesuai menurut pengertian SISMIOP oleh Dirjen Pajak.

b. Penerapan SISMIOP merupakan sarana untuk meningkatkan pelayanan kepada wajib pajak. Dengan adanya SIMIOP yang terintegrasi dengan sistem komputer dapat mempermudah dan mempercepat proses permohonan yang diajukan wajib pajak.Penerapan SISMIOP juga meningkatkan penerimaan PBB-P2. Dengan adanya SIMIOP data objek pajak dapat diperbaharui sehingga data menjadi up to date dan akurat. Peningkatan ini juga tidak terlepas dari penagihan pajak secara terus-menerus. Selain itu dengan adanya SISMIOP dapat lebih sederhana, cepat dan eifisien.

c. Kendala yang dihadapi dalam penerapan SISMIOP yaitu belum dilengkapinya alat-alat yang memadai dalam pencetakan massal. Misalnya berupa printer yang telah sesuai standar Dirjen Pajak.

\section{Saran}

a. Untuk DPPKAD Kabupaten Buol agar memberikan denda apabila WP terlambat membayar pajak. Sehingga penerimaan PBB-P2 akan meningkat dan wajib pajak juga agar jera dengan tidak lagi membayar pajak diluar jatuh tempo yang telah ditentukan.

b. Perlu adanya rekapitulasi setiap tahun mengenai berapa jumlah wajib pajak yang mengajukan surat permohanan. Ini dibutuhkan agar pemda dapat mengetahui berapa jumlah wajib pajak yang mengajukan surat permohonan pajak setiap tahun. Sehingga dapat diketahui peningakatan jumlah WP objek pajak baru, mutasi, pembetulan, dll. 
c. Lebih banyak meningkatkan SDM yang kompeten dalam penggunaan aplikasi SISMIOP dan pemda setempat dapat melengkapi sarana dan prasarana dalam menunjang aplikasi SISMIOP.

\section{DAFTAR PUSTAKA}

Ayu Metha Apsari Prathiwi, Ida, Nyoman Trisna Herawati, Ni Luh Gede Erni Sulindawati, 2015. Analisis Strategi Penerimaan Pajak Bumi dan Bangunan Pedesaan dan Perkotaan (PBB P2) Serta Efektivitas Penerimaannya Di Pemerintah Kota Denpasar. Jurnal. Singaraja.

Jacob Ratuela, Gilbert, Grace B. Nangoi, Harijanto Sabijono, 2015. Evaluasi Pelaksanaan Pemungutan Dan Prosedur Pencatatan Pajak Bumi dan Bangunan Perdesaan dan Perkotaan (PBB P2) Sebagai Pajak Daerah Di Kota Bitung. Jurnal. Manado.

Keputusan Direktorat Jendral Pajak Nomor kep-533/Pj/2000 Tentang Petunjuk Pelaksanaan Pendaftaran, Pendataan dan Penilaian Objek dan Subjek Pajak Bumi dan Bangunan Dalam Rangka Pembentukan dan atau Pemeliharaan Basis Data Sistem Manajemen Informasi Objek Pajak (SISMIOP).

Keputusan Direktorat Jendral Pajak Nomor kep-533/Pj/2000 Tentang Petunjuk Pelaksanaan Pendaftaran, Pendataan dan Penilaian Objek dan Subjek Pajak Bumi dan Bangunan Dalam Rangka Pembentukan dan atau Pemeliharaan Basis Data Sistem Manajemen Informasi Objek Pajak (SISMIOP).

L. Cameron, David, 1999. Property Tax. International Journal. Willamette University.

Nadhia, Syarifah, Siti Khairani, Ratna Juwita, 2014. Efektivitas Prosedur Penerimaan Pajak Bumi dan Bangunan (PBB) dari Pajak Pusat ke Pajak Daerah Pada Dinas Pendapatan Daerah Kota Palembang. Jurnal. Palembang.

Sharon Sumenge, Ariel, 2013. Analisis Efektifitas Dan Efisiensi Pelaksanaan Anggaran Belanja Badan Perencanaan Pembangunan Daerah (BAPPEDA) Minahasa Selatan. Jurnal. Manado.

Undang-Undang Nomor 28 Tahun 2009 Tentang Pajak Daerah dan Retribusi Daerah.

Wahyudi, Eddy, 2012. SISMIOP: Sang Sistem pengelolaan Administrasi Data PBB P2. 2015. 